\title{
Development of a Psychological Game Questionnaire
}

\author{
(C) 2021 Iming Huang
}

\begin{abstract}
A research study is described, conducted in Taiwan with 615 subjects across different ages, educational levels and occupations, to develop a questionnaire that will measure three components of psychological games: hidden messages or ulterior transactions, role switches on the drama triangle, and repressed emotions. A literature review is included and the development of the questionnaire through a pre-test option with 226 subjects is described. The results of statistical analyses are described and the final questionnaire, in English and in Chinese, is included as appendices.
\end{abstract}

\section{Introduction}

The research reported in this article was conducted by the author in connection with a Master's degree awarded by the National Chiayi University in Taiwan, under the Department of Counselling. It was stimulated by a suggestion by Marilyn Zalcman (1990) that professionals within the TA community needed to "Develop a limited number of basic paradigms (probably no more than three to six) for different types of games that qualify for theoretical game analysis." (p.12). After an appropriate literature review, three constructs were established to form the basis for the research; an initial questionnaire was developed and trialled with 226 adults, and the final questionnaire was completed by 615 adults and their results analysed. Statistical methods indicated that the questionnaire had sufficient validity that it can be recommended for use by practitioners with clients as a self-awareness instrument.

\section{Literature Review.}

Because readers will be familiar with TA concepts, the following is a summary only of the detailed information that has been contained within the thesis.

Berne (1958) published an article based on an oral presentation he had delivered the previous year, referring to the theoretical bases of TA as structural analysis, transactional analysis, game analysis and script analysis. Over the years, the concept of psychological games was introduced by Berne in several publications and particularly in his book entitled Games People Play (Berne 1964). Published posthumously, his last book (Berne 1972) provided a collation of his ideas, including analysing games using transactional diagrams and Formula $\mathrm{G}$ which set out the steps of a game. Karpman (1968) introduced the well-known drama triangle as a way of analysing games in terms of the roles of Persecutor, Rescuer and Victim.

We can consider the general TA literature across three phases: most literature published during the early period of 1965-1977 focused on the identification and naming of games, although many of the games described did not include the switch; for 1980-1989 the number of articles dropped sharply and the authors focused more on the switch within games and concepts related to games; 1990-2019 contained a special issue on games including the article by Zalcman (1990).

We can also see how Berne's other theoretical concepts provide information about games. He wrote of ego states showing up in games in terms of variations of Parent, Adult and Child structurally and how in their functional modes these may be observed as Nurturing or Controlling Parent, and Free or Adapted Child, with the latter subdivided into Compliant or Rebellious (Drye 1974). In terms of transactional analysis, games move from complementary to crossed transactions because there will have been an ulterior, psychological message. In terms of script analysis, the choice of game is seen as done so that the ending reinforces the life plan and one of the psychological life positions (Gujral and Kaur 2018; Massey 1990; Stuntz 1971).

In terms of games, although Berne (1972) used Formula $G$ to indicate that some of the previously 
existing names of games were no longer fitting the definition, Zalcman (1990) challenged the inclusion by Berne of the moment of confusion (indicated by $X$ and referred to as the cross-up by Berne). Summerton (2000) also regarded $X$ as representing a recurring and familiar moment (déjà vu). Table 1 contains a summary of how game definitions were developed by Berne (1958, 1964, 1966, 1972), together with Zalcman's (1990) version.

Based on the definitions, it is necessary to define further what is meant by the feelings denoted by the payoff. Within TA literature there are four basic feelings that are described as 'real' feelings: mad (angry), sad, glad (happy) and scared (fear) (Qu Decai 2000; Kleinewiese 1980; Stewart and Joines 1987/ 1999, 2012/2017). Individuals learn at an early age that only certain feelings are allowed and they begin to exhibit substitute feelings (English 1971, 1972). For the purposes of this research, it was recognised that sadness relates to something that has happened in the past, anger relates to something in the present, and fear relates to something in the future (Thomson 1983).

\section{Purpose of the Research}

The purpose of the research was to develop a credible and valid questionnaire that would provide information about psychological game playing by adults, in a way that would allow them and their transactional analysis practitioners to analyse their communication patterns and consider possible changes that might make these patterns more psychologically healthy.

Subject to the identification of the components of such a psychological game questionnaire, and satisfactory indications of its credibility and validity, specific questions to be answered then were proposed as whether there were differences in participation in psychological games in terms of genders, ages, educational levels or occupations.

\section{Research Methods}

As shown in Figure 1, the research structure focused on theoretical versus practical game analysis.

The main features of psychological games were identified as:

- hidden messages - coming from within the individual from negative Controlling Parent, negative Nurturing Parent, negative Compliant Adapted Child, negative Rebellious Adapted Child.

- role switches - Persecutor to Victim, Victim to Persecutor, Rescuer to Victim, Rescuer to Persecutor.

- repressed emotions - sadness (past), anger (present) and fear (future) in terms of the genuine emotions being repressed at the end of the game; with each of these measured in terms of degrees of severity.

The research process began with a literature review, followed by discussions with a Teaching \& Supervising Transactional Analyst (TSTA) and statisticians, so that a pre-test questionnaire was developed. To meet statistical requirements, this had 44 questions that covered the number of topics multiplied by 3-5 (Niu Wenying 2015).

This was tested with at least 200 individuals (Wang Wenke and Wang Zhihong 2010; Wang Junming 1999). Questions were then adjusted and/or deleted based on descriptive statistics and a final version with 33 questions was produced and completed by 615 individuals, which allowed a sample confidence level of $95 \%$ with a margin of error of $\pm 4 \%$ based on Ministry of Interior data on the parent group.

\begin{tabular}{cl}
\hline Date & Definition \\
\hline Berne (1964) & $\begin{array}{l}\text { "An ongoing series of complementary ulterior transactions } \\
\text { progressing to a well-defined, predictable outcome." (p.48) }\end{array}$
\end{tabular}

Berne (1966) "A game is a series of ulterior transactions with a gimmick, leading to a usually well-concealed but well-defined pay-off. " (p.227)

"Formula G : C(con) + G(gimmick) $=\mathrm{R}$ (responds) $\rightarrow \mathrm{S}$ (switch) $\rightarrow$

Berne (1972) X(cross-up) $\rightarrow P$ (payoffs). Whatever fits this formula is a game, and whatever does not fit it is not a game."(p.23)

Zalcman (1990)

"A well-defined series of transactions in which at least one person offers a con and eventually pulls a switch and collects a payoff." (p.12)

Table 1: Psychological Game Definitions 


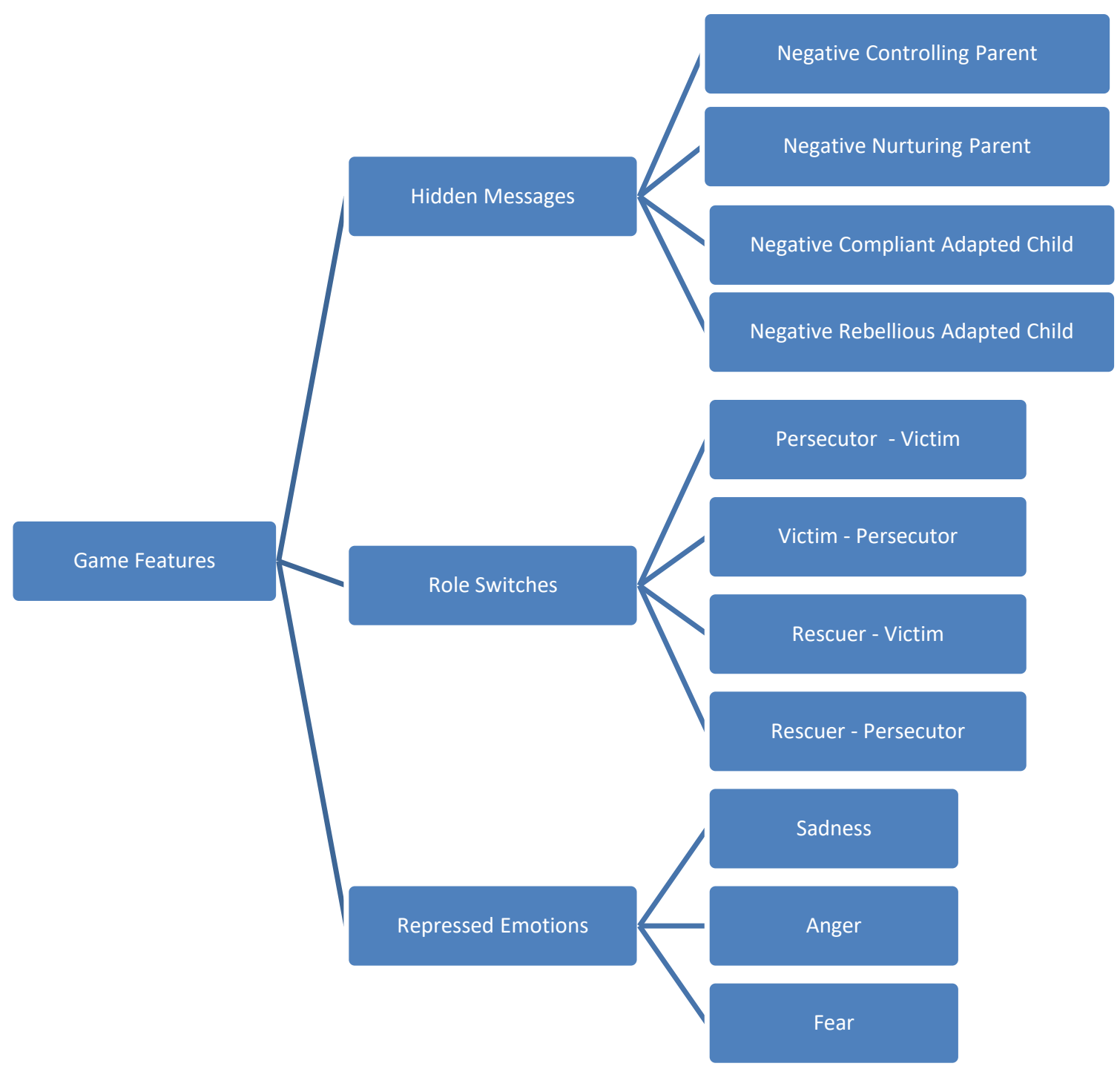

Figure 1: Schema Diagram

Data was collected for the pre-test and the final questionnaire about gender, age, education and occupation variations. Statistical analyses were done using SPSS 25.0 and AMOS 23.0.

To comply with the ethical guidelines (Wu Minglong 2014), the study only collected the subjects' answers to the questions and basic background information and not their identities. The statement about informed consent was included clearly within the questionnaire and subjects were informed that they should read the instructions in detail before going on to answer the questions. The researcher did, of course, guarantee that the results would be based only on the information provided by the subjects

\section{Changes after the Pre-Test}

Answers were analysed for any negative interpersonal pattern impact, in line with Zhu Jinfeng's (2010) recommendations about identification of these. It was found that six questions required attention and in the final version, wording was included to subjects that the results of the questionnaire were only for the purposes of their increased self-awareness so they should answer honestly and not be concerned about the opinions of others.

Cronbach's a was used to confirm consistency of direction of each of the three component questionnaires and was 0.918 for the complete questionnaire, 0.723 for Hidden Messages, 0.890 for Role Switches, 
and 0.874 for Repressed Emotions. No questions were therefore deleted.

Factor analysis was completed on the three component questionnaires (KMO and Bartlett spherical test) and several questions were deleted or adjusted until a satisfactory statistical result was obtained.

The final version of the questionnaire is included as Appendix A: English and Appendix B: Chinese. Please note, however, that Appendix $A$ is a translation and the statistical results are based on the Chinese version.

\section{Analyses of the Final Questionnaire}

Statistical analyses were conducted to check whether the questionnaire better fit the model that the three factors infer common factors or whether the three factors are related to each other, as illustrated in Figure 2. The common factors model met the recommended criteria and the related factors model almost did that with one criterion slightly below. Composite Reliability (CR) was good at $>.60$ and Average Variance Extracted (AVE) was acceptable at $>30$.

\section{Gender Analysis}

The average score for males was slightly higher than for females on the Hidden Messages section, and lower for the Role Switches and Repressed Emotions. However, the average score for adult men was only slightly lower and almost identical to that for adult women. There were also significant differences in the ratio of subjects - there were 155 males and 460 females so caution is advised over interpretation of these results.

\section{Age Analysis}

There were 169 subjects who were below 30 years old, 173 aged $30-39,147$ aged $40-49,114$ aged 50-59, and 12 over 60 years of age. There are opposing arguments about whether the final results can be relied upon - homogeneity determination is not attained but Ge Shuren (2006) would say that more confidence is justified considering the heterogeneity of the subjects. Within those caveats, the 0-29 group scored highest on the total scores and on the Hidden Messages component, whereas the 30-39 years group were higher on Role Switches and Repressed Emotions scores.

\section{Education Analysis}

The subjects were heavily drawn from university backgrounds, with 316 having attended university, another 174 having master's degrees and 8 with PhD's. The remainder were 2 individuals who had attended primary school, 2 who had attended junior high school, and 43 who had attended senior high school. Again for these groups there was a problem with homogeneity determination so it has been concluded that there are no significant differences in responses to the questionnaire from groups with the different educational backgrounds.

\section{Occupational Analysis}

Occupational categories were combined so that the classifications applied were 50 students, 95 in education, 69 in public services, 105 in the services industry, 24 within finance and insurance, 29 in IT/electronics, 39 in manufacturing, 66 in healthcare, 8 within tourism and transportation, 9 as tradespeople, 31 freelance or retired, 30 in housekeeping, 15 unemployed and 45 in agriculture, fisheries and animal husbandry.

Because of the number of different occupations and the variations in numbers of subjects, caution is required in using the scores of the different groups. However, the total score and those for Hidden Messages and Repressed Emotions are highest in those who are unemployed, with tradespeople slightly higher for Role Switches.

\section{Conclusions}

A questionnaire about psychological games has been developed with three components: Hidden Messages (Berne's ulterior transactions); Role Switches (Karpman's drama triangle); and Repressed Emotions (sad, mad, scared as they are usually labelled in the TA literature).

Statistical analyses indicate that the questionnaire is in line with various recommendations so we can now develop TA theory in terms of there being three components associated with psychological game playing, and that it is reasonable to infer that the correlation between those three components exists.

Iming Huang is a Licensed Counselling Psychologist in Taiwan, has a master's degree from the Department of Counselling at National Chiayi University, and is a student of TA. She can be contacted at iming.huang.tw@gmail.com

The author expresses her special thanks to Ms. YaYing Chen, Teaching \& Supervising Transactional Analyst (Psychotherapy), for her assistance in this research. 


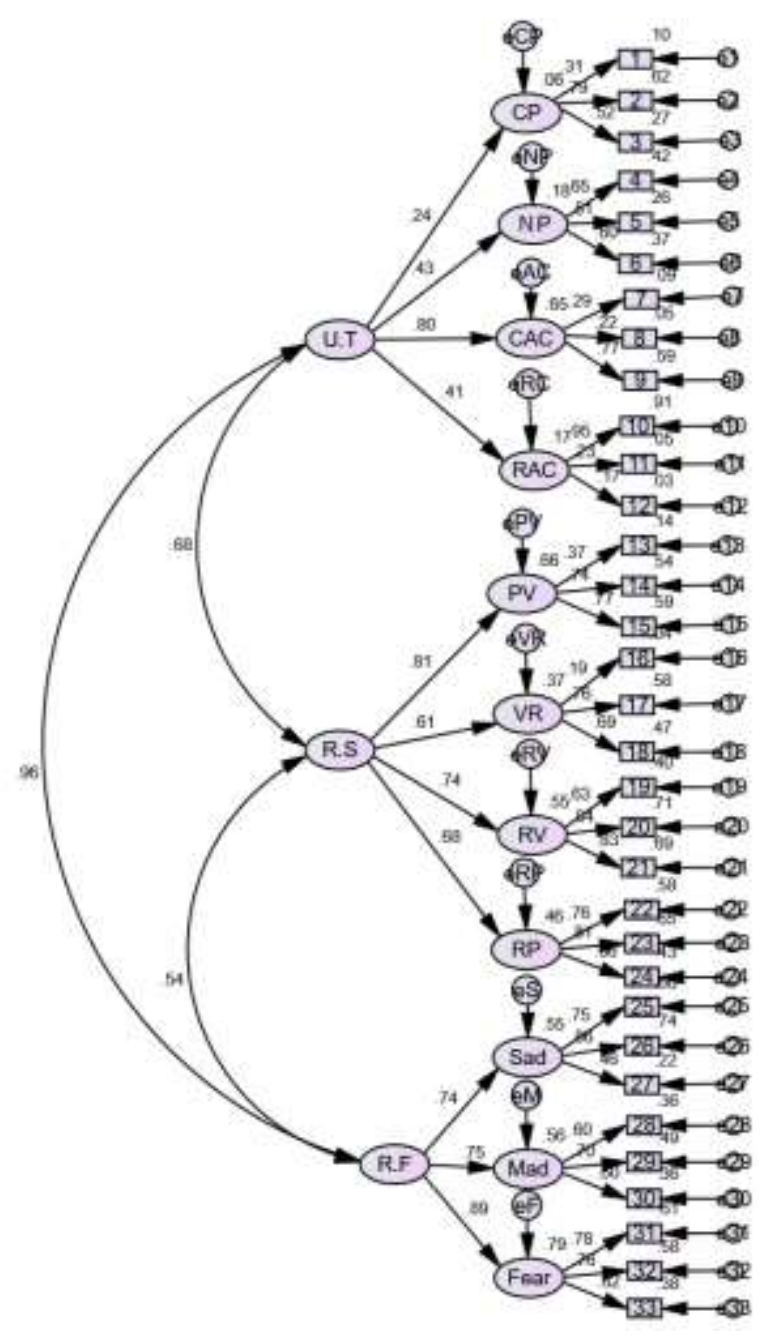

Figure 2: Models of potential relationships.

\section{References}

Berne, E. (1958). Transactional analysis: A new and effective method of group therapy. American Journal of Psychotherapy, 12(4), 735-743.

Berne, E. (1964). Games people play: The psychology of human relationships. Andre Deutsch.

Berne, E. (1966).Principles of group treatment. Grove Press.

Berne, E. (1972). What do you do after you say hello? Grove Press.

Drye, R. C. (1974). Stroking the Rebellious Child. Transactional Analysis Journal, 4(3), 23-26. https://doi.org/10.1177/036215378001000210

English, F. (1971). The substitution factor: Rackets and real feelings: Part I. Transactional Analysis Journal, 1(4), 27-32.

https://doi.org/10.1177/036215377100100408

English, F. (1972). Rackets and real feelings: Part II. Transactional Analysis Journal, 2(1), 23-25. https://doi.org/10.1177/036215377200200108

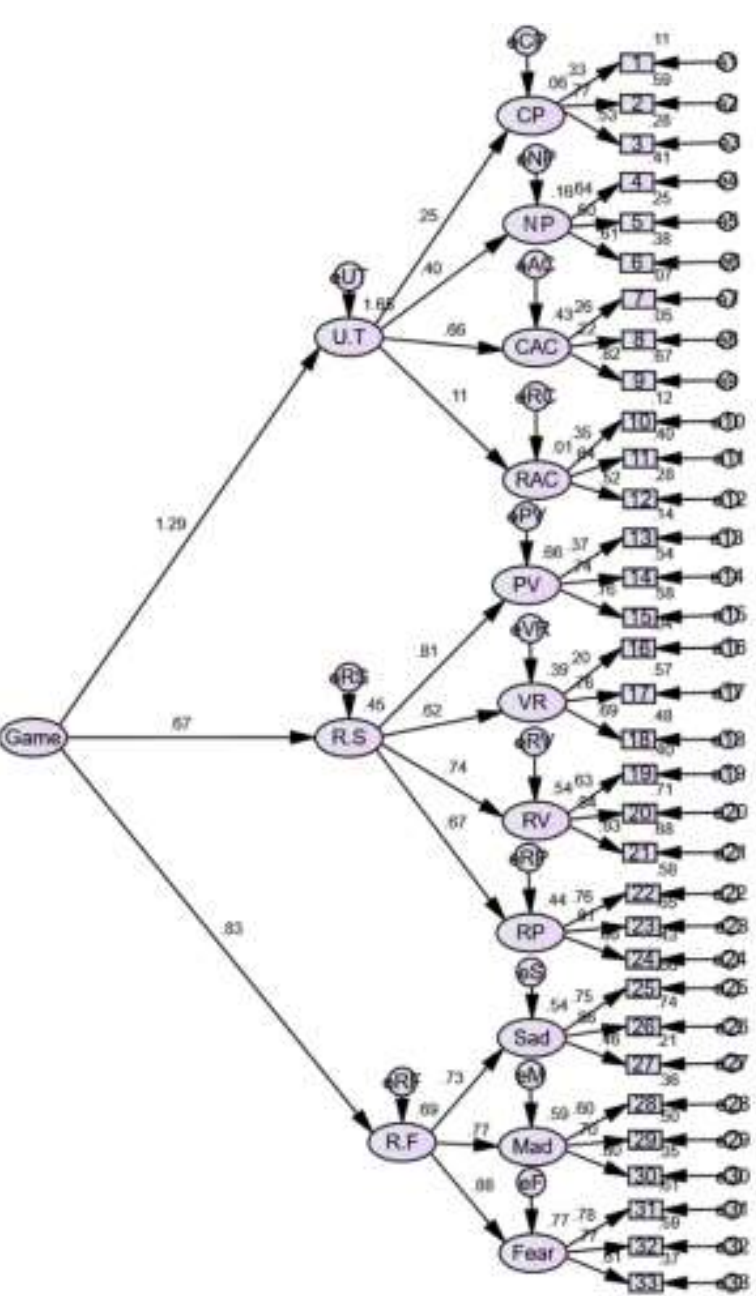

Ge Shuren (2006). Psychometrics. Laurel Wreath.

Gujral, H. K., \& Kaur, J. (2018). Life Script:

Determinants and Outcomes. International Journal of

Research in Economics and Social Sciences (IJRESS), 8(3), 738-747.

https://www.researchgate.net/profile/Harminder Gujr al/publication/325569361 LIFE SCRIPT DETERMIN ANTS AND OUTCOMES/links/5b165f434585151f91 fb8056/LIFE-SCRIPT-DETERMINANTS-ANDOUTCOMES.pdf

Karpman, S. (1968). Fairy tales and script drama analysis. Transactional Analysis Bulletin, 7(26), 3943.

Kleinewiese, E. (1980). TA with Children: Visual Representation Model of the Ego States.

Transactional Analysis Journal, 10(3), 259-263. https://doi.org/10.1177/036215378001000318

Massey, R. (1990). The Structural Bases of Games. Transactional Analysis Journal, 20(1), 20-27. https://doi.org/10.1177/036215379002000103 
Niu Wenying (2015). Research methods and essay writing 2nd edition (revised). Futaba.

Qiu Decai (2000). TA's consultation process and technology. Teacher Zhang.

Stewart, I. \& Joines, V. (1987). TA today: a new introduction to transactional analysis. Lifespace Publishing. [Teacher Zhang 1999 version in Chinese]

Stewart, I. \& Joines, V. (2012). TA today: a new introduction to transactional analysis $2^{\text {nd }}$ edn. Lifespace Publishing [2017 version in Chinese, World Books]

Stuntz, E. C. (1971). Classification of Games by Positions. Transactional Analysis Journal, 1(4), 5760. https://doi.org/10.1177/036215377100100413

Summerton, O. (2000). The Development of Game Analysis. Transactional Analysis Journal, 30(3), 207218. https://doi.org/10.1177/036215370003000305
Thomson, G. (1983). Fear, Anger, and Sadness. Transactional Analysis Journal, 13(1), 20-24. https://doi.org/10.1177/036215378301300105

Wang Junming (1999). Compilation and analysis methods of questionnaires and scales. Sports Quiz and Evaluation, 139-158.

https://physical.ntsu.edu.tw/var/file/12/1012/img/451/0 $\underline{04 . p d f}$

Wang Wenke \& Wang Zhihong (2010). Educational Research Method. Wunan.

Wu Minglong (2014). Essay writing and quantitative research (updated 4th edition). Wunan.

Zalcman, M. (1990). Game Analysis and Racket Analysis: Overview, Critique, and Future Developments. Transactional Analysis Journal, 20(1), 4-19. https://doi.org/10.1177/036215379002000102

Zhu Jinfeng (2010). Theory and application of psychological testing. Futaba. 


\section{Appendix A: Psychological Game Questionnaire (English)}

\begin{tabular}{|c|c|c|}
\hline & Question & Frequency \\
\hline 1 & $\begin{array}{l}\text { When the other person is late for no reason, I will keep my face } \\
\text { blank and wait for them. }\end{array}$ & $1-2-3-4-5-6$ \\
\hline 2 & $\begin{array}{l}\text { I will convince the other side to listen to me if I can't agree with the } \\
\text { proposal. }\end{array}$ & $1-2-3-4-5-6$ \\
\hline 3 & $\begin{array}{l}\text { When I find that there is an omission by another party, I will correct } \\
\text { them. }\end{array}$ & $1-2-3-4-5-6$ \\
\hline 4 & In order to get things done quickly, I will step in to help others. & $1-2-3-4-5-6$ \\
\hline 5 & I am one call away when the other person needs me. & $1-2-3-4-5-6$ \\
\hline 6 & $\begin{array}{l}\text { For others' own good, I will take the initiative to help others make } \\
\text { decisions. }\end{array}$ & $1-2-3-4-5-6$ \\
\hline 7 & I don't say a word when I'm scolded by another person. & $1-2-3-4-5-6$ \\
\hline 8 & $\begin{array}{l}\text { Whatever the reason for the quarrel, l'll bow my head and apologize } \\
\text { to the other person first. }\end{array}$ & $1-2-3-4-5-6$ \\
\hline 9 & When people question me, I will doubt myself as well. & $1-2-3-4-5-6$ \\
\hline 10 & $\begin{array}{l}\text { When another person doesn't want to listen to what I think, I become } \\
\text { silent. }\end{array}$ & $1-2-3-4-5-6$ \\
\hline 11 & I will ignore another party's unreasonable request to me. & $1-2-3-4-5-6$ \\
\hline 12 & $\begin{array}{l}\text { Even if another person tries to convince me, I don't change my mind } \\
\text { easily. }\end{array}$ & $1-2-3-4-5-6$ \\
\hline 13 & $\begin{array}{l}\text { The act of asking for help only when I face difficulty makes the other } \\
\text { person misunderstand me. }\end{array}$ & $1-2-3-4-5-6$ \\
\hline 14 & A moment of careless talk leads me into more trouble. & $1-2-3-4-5-6$ \\
\hline 15 & $\begin{array}{l}\text { I will do anything to prove another person's mistakes, even when it } \\
\text { causes problems for me to do that. }\end{array}$ & $1-2-3-4-5-6$ \\
\hline 16 & if others criticize me behind my back. & $1-2-3-4-5-6$ \\
\hline 17 & When I'm under too much pressure, I vent my anger on others. & $1-2-3-4-5-6$ \\
\hline 18 & $\begin{array}{l}\text { The grievances I suffer in a relationship will make me argue with the } \\
\text { other person. }\end{array}$ & $1-2-3-4-5-6$ \\
\hline 19 & $\begin{array}{l}\text { When I am enthusiastic and active, people think I should mind my } \\
\text { own business. }\end{array}$ & $1-2-3-4-5-6$ \\
\hline 20 & I get too involved in dealing with other people's problems. & $1-2-3-4-5-6$ \\
\hline 21 & $\begin{array}{l}\text { When I help other people solve problems I have to clean up what } \\
\text { happens afterwards. }\end{array}$ & $1-2-3-4-5-6$ \\
\hline 22 & $\begin{array}{l}\text { I listen patiently to others' complaints, but the advice I offer makes } \\
\text { them unhappy. }\end{array}$ & $1-2-3-4-5-6$ \\
\hline 23 & $\begin{array}{l}\text { I try my best to cheer others up, but it seems they feel more } \\
\text { depressed. }\end{array}$ & $1-2-3-4-5-6$ \\
\hline 24 & $\begin{array}{l}\text { The way I solve problems leads others think I'm shirking my } \\
\text { responsibility. }\end{array}$ & $1-2-3-4-5-6$ \\
\hline 25 & $\begin{array}{l}\text { I feel sad when I quarrel with someone because of my own } \\
\text { negligence. }\end{array}$ & $1-2-3-4-5-6$ \\
\hline 26 & $\begin{array}{l}\text { When I am misunderstood, I feel sad because the other person } \\
\text { doesn't believe me. }\end{array}$ & $1-2-3-4-5-6$ \\
\hline 27 & I do things to save face for others and then I feel resentful. & $1-2-3-4-5-6$ \\
\hline 28 & $\begin{array}{l}\text { Every time I think about what the other person has done to me, I still } \\
\text { feel angry. }\end{array}$ & $1-2-3-4-5-6$ \\
\hline 29 & $\begin{array}{l}\text { When things don't go as well as expected, I show impatience with } \\
\text { others. }\end{array}$ & $1-2-3-4-5-6$ \\
\hline 30 & I get angry when others do things to me that i don't want them to do. & $1-2-3-4-5-6$ \\
\hline 31 & I am disturbed if others speak in an aggressive way. & $1-2-3-4-5-6$ \\
\hline 32 & Being pushed by others can make me nervous. & $1-2-3-4-5-6$ \\
\hline 33 & $\begin{array}{l}\text { After a quarrel ends in discord, I am afraid the other side will ignore } \\
\text { me. }\end{array}$ & $1-2-3-4-5-6$ \\
\hline
\end{tabular}




\section{Appendix B: Psychological Game Questionnaire (Chinese)}

\begin{tabular}{|c|c|c|}
\hline & 量表題 目 & 發生頻率圈選 \\
\hline 1. & 當對方無故遲到時，我會擺起臉孔等對方。 & $1-2-3-4-5-6$ \\
\hline 2. & 無法認同的提議，我會說服對方聽我的。 & $1-2-3-4-5-6$ \\
\hline 3. & 發現對方有疏失時，我會糾正對方。 & $1-2-3-4-5-6$ \\
\hline 4. & 為了讓事情趕緊完成，我會插手幫忙對方。 & $1-2-3-4-5-6$ \\
\hline 5. & 只要對方有需要，我會隨傳隨到。 & $1-2-3-4-5-6$ \\
\hline 6. & 為了對方好，我會主動幫對方做決定。 & $1-2-3-4-5-6$ \\
\hline 7. & 受到對方責備時，我會不發一語。 & $1-2-3-4-5-6$ \\
\hline 8. & 不管爭吵的原因是什麼，我會先低頭向對方道慊。 & $1-2-3-4-5-6$ \\
\hline 9. & 當對方對我有所質疑時，我也會對自己產生懷疑。 & $1-2-3-4-5-6$ \\
\hline 10. & 當對方不想聽我的想法時，我會變得沉默不語。 & $1-2-3-4-5-6$ \\
\hline 11. & 對方對我的無理要求，我會當耳邊風不予理會。 & $1-2-3-4-5-6$ \\
\hline 12. & 即使對方費盡唇舌想說服我，我也不會輕易改變決定。 & $1-2-3-4-5-6$ \\
\hline 13. & 我有困難才開口的行為，讓對方對我有所誤會。 & $1-2-3-4-5-6$ \\
\hline 14. & 遠一時的口舌之快，卻讓自己惹上更多麻煩。 & $1-2-3-4-5-6$ \\
\hline 15. & 想辦法證明對方的錯誤，反讓自己賠了夫人又折兵。 & $1-2-3-4-5-6$ \\
\hline 16. & 面對他人在我背後造謠，我會找機會還自己公道。 & $1-2-3-4-5-6$ \\
\hline 17. & 當承受壓力過大時，我會遷怒旁人。 & $1-2-3-4-5-6$ \\
\hline 18. & 關係中承受的委屈，會讓我跟對方起爭執。 & $1-2-3-4-5-6$ \\
\hline 19. & 我熱心積極的個性，卻被對方視為干預過多。 & $1-2-3-4-5-6$ \\
\hline 20. & 處理對方的麻煩事，自己卻成為當事者。 & $1-2-3-4-5-6$ \\
\hline 21. & 協助對方解決問題，卻變成我要收拾善後。 & $1-2-3-4-5-6$ \\
\hline 22. & 我耐心地聽對方訴苦，但提供的建議卻讓對方不開心。 & $1-2-3-4-5-6$ \\
\hline 23. & 我盡力為對方加油打氣，卻反讓對方意志更消沉。 & $1-2-3-4-5-6$ \\
\hline 24. & 我解決問題的方式，讓對方認為我推卸責任。 & $1-2-3-4-5-6$ \\
\hline 25. & 和對方因我個人疏失吵架時，我會覺得難過。 & $1-2-3-4-5-6$ \\
\hline 26. & 在受到誤解時，我會因對方不相信我而覺得傷心。 & $1-2-3-4-5-6$ \\
\hline 27. & 我會為了顧全對方面子，而讓自己承受委屈。 & $1-2-3-4-5-6$ \\
\hline 28. & 每每想起對方對我的所作所為，我仍感到憤怒。 & $1-2-3-4-5-6$ \\
\hline 29. & 當事情不如預期時，我會對他人表現出不耐煩的樣子。 & $1-2-3-4-5-6$ \\
\hline 30. & 當對方踩到我的地雷時，我會感到生氣。 & $1-2-3-4-5-6$ \\
\hline 31. & 對方咄咄逼人的說話方式，讓我感到不安。 & $1-2-3-4-5-6$ \\
\hline 32. & 他人對我的催促，會讓我感到緊張。 & $1-2-3-4-5-6$ \\
\hline 33. & 吵架不歡而散後，我會怕對方不理我。 & $1-2-3-4-5-6$ \\
\hline
\end{tabular}

